\title{
The Role of Emotion, Values, and Beliefs in the Construction of Innovative Work Realities
}

\author{
Isabel Ramos ${ }^{1}$, Daniel M. Berry² ${ }^{2}$ and João Á. Carvalho ${ }^{3}$ \\ 1 Escola Superior de Tecnologia e Gestão de Viana do Castelo, \\ Viana do Castelo, Portugal \\ isantos@mail.telepac.pt \\ 2 Department of Computer Science, University of Waterloo, \\ Waterloo, ON, Canada \\ dberry@uwaterloo.ca \\ 3 Departamento de Informática, Universidade do Minho, \\ Guimarães, Portugal \\ jac@dsi.uminho.pt
}

\begin{abstract}
Traditional approaches to requirements elicitation stress systematic and rational analysis and representation of organizational context and system requirements. This paper argues that (1) for an organization, a software system implements a shared vision of a future work reality and that (2) understanding the emotions, feelings, values, beliefs, and interests that drive organizational human action is needed in order to invent the requirements of such a software system. This paper debunks some myths about how organizations transform themselves through the adoption of Information and Communication Technology; describes the concepts of emotion, feeling, value, and belief; and presents some constructionist guidelines for the process of eliciting requirements for a software system that helps an organization to fundamentally change its work patterns.
\end{abstract}

\section{Introduction}

Before the 90s, software systems were used mainly for automating existing tasks or for collecting or delivering information. With the rapid development of Information and Communication Technology (ICT), software systems became a driver for innovative work practices and for new models of management and organization [12].

Terms like "globalization", "knowledge management", "organizational learning", "collaborative work", "value creation", "extended enterprise", "client relationship management", and "enterprise resource planning", among others, are creating a new understanding of human action in organizations. We are learning that action is enabled, empowered, or extended by ICT. As a consequence, individuals and organizations can now be more creative, flexible, and adaptive. We have more complex and volatile environments and organizations. Change is presented as inevitable. Holistic approaches to change management and the 
development of software systems are seen as imperative in order to cope with organizational complexity.

Nearly everyone seems to accept that environments in which change emerges or is induced are incredibly complex. Thus, the software systems that are supposed to help organizations adapt or transform themselves are inherently complex. Their essence, their requirements defy rapid or systematic understanding. Yet, the development of these software systems is still expected to occur in a more orderly systematic fashion, at a well defined point in time, and to be as cheap and quick as possible.

The goals that drive the process are often economic and structural. These goals include the improvement of organizational efficiency and effectivness, the reduction of costs, and the improvement of individual or group performance. The lofty goals notwithstanding, it is very difficult get these software systems to be used successfully and effectively [27], [18]. People in organizations resist the changes. They resist using the systems, misuse them, or reject them. As a result, the goals are not achieved, intended changes are poorly implemented, and development budgets and schedules are not respected. Misplaced emotions, values, and beliefs are often offered as the causes of these problems.

Accordingly, this paper

- debunks some myths about how organizations transform themselves through the adoption of ICT applications;

- describes the concepts of emotion, value, and belief and how they affect development and acceptance of software systems; and

- presents some constructionist guidelines for the process of eliciting requirements for software systems that help organizations to fundamentally change their work patterns.

\section{Organizational Transformation Supported by the Adoption of Innovative Software Systems}

Organizational transformation (OT) is the process of fundamentally changing an organzation's processes in order to allow it to better meet new challenges. It is often accompanied by the introduction of new software systems that make the new process possible. OT in an organization is often prompted when it begins to consider how it might automate its process. The organization realizes that just automating current processes is a waste of computing resources. The current processes were designed over the years to allow the organization to function in a unautomated, paper-driven environment. Data on paper are often accurate only to the day or longer. Automating current processes maintains these manual, paper-driven processes, when a computer and its software has the potential of providing a highly dynamic, automated, paper-free process with information accurate to the second rather than to the day or longer.

OT is connected not only to automating an organization's processes. Even an organization with fully automated processes may engage in OT. Other triggers 
for OT include implementing a new management or business model, adopting a new best practice, desiring to satisfy clients better, creating a new internal or external image, promoting a new social order, obeying environmental rules, fostering collaborative practices, etc. Sometimes, OT is triggered as a consequence of internal political fights.

We must explain the use, in this paper, of the word "transformation" instead of "change". Both words mean change, in the general sense, but the technical term "transformation" means radical change and the technical term "change" means evolutionary change. Evolutionary change refers to efficiency improvements, local quality improvements, change in procedures, and all kinds of localized change that have minor impact on the overall organization. Transformation implies fundamental changes of meanings and practices relevant to individual workers, groups, or the organization. Transformation means a change of identity. In whatever social order it occurs, it will have a big internal and environmental impact on the organization.

\subsection{Rhetoric and Myths About Organizational Transformation}

Some authors [7], [16], [19], [23], [5], [8] present OT as a process that can be planned, managed, and controlled. According to these authors, OT is a rational and controllable process that can be systematicall implemented using well-tested methods and techniques to guide it. Consequently, OT can be made predictable, quick, and reasonably cheap. OT is best led by consulting firms that are experts in the field. OT is often directed to the organizational structure: goals and strategies, processes, tasks and procedures, formal communication channels, coordination and control of activities, work needs, and authority levels. Finally, OT is expected to have impact on relevant concepts and practices and on political relations.

Resistance to transformation of meanings and practices is often expected. This resistance is seen as a problem to solve or minimise as soon as possible. Individuals are expected to adhere to values such as flexibility, creativity, collaboration, and continuous learning. They are expected to be motivated to immediately, effectively, and creatively use the delivered system.

Every planned OT is seen initially as positive. In the end, the OT may fail. Since the OT is often justified by economic or political reasons, the failure is considered critical to the organization. Thus, there must be blame for the failure. The failure is often blamed on the leaders of the failed process, the consulting firms that failed to implement it, or the individuals and groups that failed to change. Ethical and moral considerations about the way the process was led and about the obtained results are rarely considered, let alone reported.

ICT applications are often seen as drivers of the intended OTs. They are adopted to foster collaborative work, improve organizational learning, make knowledge management effective, and so on.

This brief description of the rhetoric surrounding OT processes implicitly exposes several myths about the process and about people as agents and beneficiaries or victims of the transformation. 


\subsection{Organizations as Separate Entities}

We tend to see an organization as a separate entity with its own goals, strategies, potentialities, and constraints. However, an organization is the people that bring it to existence [13]. Goals and strategies emerge from the sense-making processes that continually reshape how an individual perceives herself and the others in the organization. This understanding leads to two main insights:

1. The idea of an organization being a separate entity with its own goals and strategies serves mainly management interests. Traditionally, management responsibilities involve the co-ordination and control of individual and subgroup efforts, in order to guarantee the economic, social, and political success of the organization. The strategy is to limit emotions, interests, values, and beliefs that could reduce the probability of achieving the goals and to implement strategies that management has defined as the best for the organization.

2. Each of us has interests, beliefs, and, sometimes, values that are not in tune with the organizational identity that, maybe, someone else is trying to solidify. Of course, this potential conflict is why participation in decision processes is so important a theme in the social sciences. Nevertheless, when consensus is not possible, there is the possibility of negotiation. There is always the possibility of giving up some interests and beliefs in exchange for other advantages. The imposition of decisions by powerful individuals or groups should be the last resort. Both negotiation and imposed decisions may lead to the emergence of negative emotions such as frustration, fear, anger, and depression. They may appear on the surface, or they may be held in silence. They may have unpredictable consequences for the development of organizational identity and for organizational success.

\subsection{Emotions, Values and Beliefs, and Change}

It is useful to define the three concepts used to construct the core ideas in this paper (1) emotions, (2) values and beliefs, and (3) change.

Emotions According to Damásio [9], there are two types of emotions, (1) background emotions and (2) social emotions. Background emotions include the sensations of well being and malaise; calmness and tension; pain and pleasure; enthusiasm and depression. The social emotions include shame; jealousy; guilt; and pride.

There is a biological foundation that is shared by all these emotions:

- Emotions are complex sets of chemical and neuronal responses that emerge in patterns. Their purpose is to help preserve the life of the organism.

- Even if learning processes and culture are responsible for different expressions of emotions and for attaching different social meanings to them, emotions are biologically determined. They depend on cerebral devices that are innate and founded in the long evolutionary history of life on Earth. 
- The cerebral devices upon which emotions depend may be activated without awareness of the stimulus or without the exercise of will.

- Emotions are responsible for profound modifications of body and mind. These modifications give rise to neuronal patterns that are at the basis of the feelings of emotion.

- When someone experiences an emotion and expresses and transforms it into an image, it can be said that she is feeling the emotion. She will know that the feeling is an emotion when the process of consciousness is added to the processes of emoting and feeling.

This complex notion of what are emotions, feelings, and awareness of feelings helps us to understand why OT will never be instrumental, quick, or without high costs. The notions of value and belief also reinforce this understanding.

Values and Beliefs Human values are socially constructed concepts of right and wrong that we use to judge the goodness or badness of concepts, objects, and actions and their outcomes [17]. The beliefs that a person holds about the reality in which he lives define for him the nature of that reality, his position in it, and the range of possible relationships to that reality and its parts [25].

As is easily seen, the physiological and sociological nature of emotions and the fact that values and beliefs are deeply rooted in personal and human history challenges the myth that OTs can be fully planned, managed, and controlled, i.e., instrumentally implemented. OT concepts and practices often lead to radical changes in cherished and long-held beliefs and values. A radical change of the way in which we understand our reality and our roles and actions in it will trigger background and social emotions that need to be carefully dealt with by creating trustful spaces of interaction, patiently over time.

An anecdote illustrates this issue. Suppose that Joe dislikes the color blue. No one can force him to like it. He can be forced to show some appearance of liking it, but then there is no transformation in his color preferences, and the forcing only increases his dislike for blue. He could be brainwashed, but brainwashing would hardly be considered an enlightened technique. Joe may be convinced of the advantages of liking blue, thus ensuring his motivation to cooperate with the transformation process. However, not even Joe can guarantee the transformation of his color preferences. Nevertheless, if Joe is motivated to cooperate there are, in effect, some strategies to improve the chances of a successful transformation:

- by conjuring emotionally positive experiences from Joe's past involving blue sensations, e.g., a peaceful, leisurely sunny summer afternoon with a crystalclear blue sky spent with his girlfriend wearing a blue bathing suit, or

- by constructing pleasant views of Joe's future involving blue sensations, e.g, a peaceful, leisurely sunny summer afternoon with a crystal-clear blue sky spent with his girlfriend wearing a blue bathing suit.

This anecdote shows also that an OT process can never be without a high expenditure of the resources needed to improve the chances of making it a success [29]. 
From everything said so far, it becomes clear also that resistance to change is natural in human beings. Because a transformation's implementers are as human as the target group, they need to find also the roots of their own resistance. That is, when the implementers are trying to minimise resistance, they may end up resisting the arguments by the process subjects that suggest changes in the implementers' thinking, strategies, and plans.

Change Nowadays, there are many mythological OTs fostered by management and ICT gurus. In the name of so-called best practices, there is little consideration for their ethical and moral implications. The implementation of complex systems, such as Enterprise Resource Planning systems, are rarely preceded by considerations about [4], [30], [41], [34], [20]:

- the system's degradation of the employees' quality of work life, by reducing job security and by increasing stress and uncertainty in pursuing task and career interests;

- the system's impact on the informal communication responsible for friendship, trust, feeling of belonging, and self respect;

- the power imbalances the system will cause; and

- the employees' loss of work and life meaning, which leads to depression.

\subsection{Summary}

In summary, this section has addressed some myths about organizational transformation in order to advance the idea that OT that challenges meaning structures is difficult, resource consuming, and influenced by emotions in situations that require trust between the participants of the OT process [6], [3], [24]. Because most actual OTs draw with them the adoption of complex software systems that support new work concepts and practices, the elicitation of the requirements of those systems must include the understanding of the involved emotions, values, beliefs, and interests.

The next section presents a constructionist perspective [21], [33] of requirements elicitation that takes into account emotions, values and beliefs, and change. Some general guidelines are offered to understand the structural, social, political, and symbolic work dimensions [4] in which values, beliefs, and interests are expressed. The section also includes guidelines for reading the emotions that elicitors and participants express in the informal and formal dialogues that occur during the process.

\section{Requirements Elicitation}

Traditionally, requirements engineering assumes a strong reality [11], [10], [39], [28], [40], [2], [22], [37], [42], [31]. The requirements engineer elicits information from this strong reality and proceeds systematically to a requirments specification. 


\subsection{Socially Constructed Reality}

Deviating from this tradition and viewing reality as socially constructed implies several epistemological and methodological assumptions, including [38], [1]:

1. Reality is constructed through purposeful human action and interaction.

2. The aim of knowledge creation is to understand the individual and shared meanings that define the purpose of human action.

3 . Knowledge creation is informed by a variety of social, intellectual, and theoretical explorations. Tools and techniques used to support this activity should foster such explorations.

4. Valid knowledge arises from the relationship between the members of some stakeholding community. Agreements on validity may be the subject of community negotiations regarding what will be accepted as truth.

5. To make our experience of the world meaningful, we invent concepts, models, and schemes, and we continually test and modify these constructions in the light of new experience. This construction is historically and socio-culturally informed.

6. Our interpretations of phenomena are constructed upon shared understandings, practices, and language.

7. The meaning of knowledge representations is intimately connected with the authors' and the readers' historical and social contexts.

8. Representations are useful if they emerge out of the process of questioning the status-quo, in order to create a genuinely new way of thinking and acting.

9 . The criteria by which to judge the validity of knowledge representations include that the representations [26]

- are plausible for those who were involved in the process of creating them,

- can be related to the individual and shared interpretations from which they emerged,

- express the views, perspectives, claims, concerns, and voices of all stakeholders,

- raise awareness of one's own and others' mental constructions,

- prompt action on the part of people involved in the process of knowledge creation, and

- empower that action.

The social construction of reality emerges from four main social processes: subjectification, externalization, objectification, and internalization [1].

Subjectification is the process by which an individual creates her own experiences. How an individual interprets what is happening is related to the reality she perceives. This reality is shapped by her subjective conceptual structures of meaning.

Externalization is the process by which people communicate their subjectifications to others, through a common language. By making something externally available, we enable others to react to our previously subjective experiences and thoughts. By means of this communication, humans may transform the original content of a thought and formulate another that is new, refined, changed or 
developed. The mutual relation with others is dialectical and leads to continuous reinterpretation and change of meanings. Surrounding reality is created by externalization.

Objectification is the process by which an externalized human act might attain the characteristic of objectivity. Objectification happens after several reflections, reinterpretations, and changes in the original subjective thoughts, when the environment has generally started to accept the externalization as meaningful. This process can be divided into phases: institutionalization and legitimization.

Internalization is the process by which humans become members of the society. It is a dialectic process that enables humans to take over the world in which others already live. This is achieved through socialization occuring during childhood, and in learning role-specific knowledge and the professional language associated with it.

\subsection{A Constructivist Perspective of Requirements Elicitation}

These core ideas have implications for practice of requirements engineering. Specifically for requirements elicitation, which is the focus of this paper, these implications are summarized in Table 1, found after the bibliographical references. This table works on three subprocesses of requirements elicitation:

1. the creation of knowledge about the current work situation, perceived problems or expectations, and the vision of a new work situation that includes the use of a software system that supports or implements innovative work concepts and practices;

2. the representation of the created knowledge; and

3. the joint invention by all stakeholders of requirements for a system that acceptably meets all stakeholder's needs, expectations, or interests.

These subprocesses, of course, are interconnected processes that are described here independently to simplify their analyses. The table has one column for each of these subprocesses. The rows represent the constructionist perspective on project goals; the process structure; the final product; the use of theoretical frameworks; methods, techniques, and tools; the role of the participants; and the reuse of previous product.

According to the constructionist perspective, knowledge is a social product, actively constructed and reconstructed through direct interaction with the environment. In this sense, knowledge is a real-life experience. As such, it is personal, sharable through interaction, and its nature is both rational and emotional. Knowledge representation is intimately connected with the knower-teacher and the learner. Knowledge representation is never complete or accurate since it can never replace the experience from which it is derived. However, a knowledge representation can be useful if it makes ideas tangible and enables communication and the negotiation of meanings. A system requirement is a specific form of knowledge representation. 


\subsection{Integration of Organizational Theory into Requirements Elicitation}

Recently, a number of authors, e.g., Bolman and Deal [4], Morgan [30], and Palmer and Hardy [32], attempted systematizations of organizational theory. Ramos investigated the usefulness of integrating this organizational theory into the requirements engineering process [35]. She described the importance of the structural, social, political, and symbolic dimensions of work in determining requirements. One result of this work are guidelines for understanding the meaning of human action and interaction. These guidelines are summarized in Tables 2 and 3 , found after the bibliographical references.

Table 2 helps decide which stakeholders should be consulted during elicitation, that is, which participants should be chosen to represent the various work dimensions. For each dimension of work, the table lists the properties of the chosen individuals that must be considered.

Table 3 shows for each dimension of work, the human actions and interactions that can be relevant to requirements.

\subsection{Towards a Constructivist Requirements Elicitiation Process}

During requirements elicitation, all created knowledge should be represented and continually consulted about how previous and actual historical, social, and cognitive experiences have been shaping the process of its creation.

While creating the knowledge elements included in Tables 2 and 3, elicitors and the system's stakeholders participate in conversations. In these conversations, the processes of subjectification, externalization, objectification, and internalization are occurring continually, and their interplay creates a common reality for elicitors and stakeholders.

Logic and emotion, awareness and unawareness, explicit and tacit are everpresent elements in the interactions, shaping thinking and action. Emotions, feelings, unconscious experience, and knowledge can be accessed only indirectly through the actions and reactions of the participants in requirements elicitation and through their use of language in its most general sense [20]:

- vocal characterizers (noises one talks through, e.g., laughing, whispering, yelling, crying);

- vocal segregates (sounds used to signal agreement, confusion, understanding, e.g., "hmm-hmm", "Huh?!", "Ah!", "Nu?!");

- voice qualities (modifications of language and vocalizations, e.g., pitch, articulation, rhythm, resonance, tempo);

- idiom (dialect, colloquialism, jargon, slang);

- discourse markers ("well", "but", "so", "okay");

- stylistic devices (use of repetition, formulatic expressions, parallelism, figurative language, onomatopoeia, pauses, silences, mimicry);

- facial expressions (smile, frown, furrowed brow);

- gestures (nodding, arm, motions, hand movements); 
- shifts in posture;

- alterations in positioning from intimacy (touching) to social or public distance;

- performance spaces (an allocated room or impromptu meeting in a corridor, rearranged seating, etc.);

- props (especially for ceremonial oratory); and

- clothing, cosmetics, and even fragrance.

During the knowledge construction process, the elicitors should reflect critically on themselves as practitioners. This reflection has mainly three dimensions:

1. What theories and practical experience has been shaping our practice as elicitors? What are the alternatives? Why should we stick to our usual ways of thinking and acting?

2. What frameworks will we be using to guide our actions in the present situation? Why? What goals will guide the interaction with members of this community? What ethical considerations are we assuming?

3. How effective is our communication with the system's stakeholders? What feelings have been present in interactions with them? What have we learned? In which way are our and others' understandings and practice changing?

These guidelines are derived from case studies carried out by the first author for her Ph.D. dissertation [35], [36]. Two case studies were carried out in order to identify what needs, expectations, and beliefs were sustaining specific OTs in which ICT applications (1) were being adopted to foster use of practices that the senior management thought to be the best and (2) were being locally developed in opposition to work concepts and practices that senior management thought were best. In each case, the OT was carried out successfully.

\section{Conclusions and Future Work}

This paper was written with the primary aim of addressing the implications of emotions, values, beliefs, and interests in the conception and adoption of software systems that support new work realities. The secondary aim of the paper is to advance some general guidelines to understand the emotions, values, beliefs, and interests relevant to requirements' elicitation.

The approach to requirements elicitation implicit in the guidelines is lengthy and resource intensive. The transformation of values, beliefs and interests, and the emotions and feelings attached to them is difficult and uncertain. It requires patience and trust. At the end of a successful OT process that includes the adoption of ICT applications, stakeholders and requirements engineers will find themselves transformed in some way. In a joint effort, they will have conceived the support of a new work reality that will be implemented. This new reality must be nurtured until it solidifies close to the way it was originally envisioned.

Addressing only the structural, political, and economic aspects of the process would mean to ignore that emotions and feelings are present even in our most 
rational and objective decisions [9]. In the elicitation of requirements, emotions and feelings are present in the choice of the problem to address, the choice of techniques and tools to gather information about business goals and work practices, the choice of stakeholders and the needs they express, the abstractions and partitions of reality, the knowledge we find relevant, the requirements we elicit, and the formats in which we choose to represent knowledge and requirements.

In future research, the guidelines will be made more detailed so that engineers can choose the ones they will integrate into their preferred methods for elicitation. It is already planned to do several cases studies in which, by studying the implementation of the same ready-to-use package of software in different organizations, the differences in the historical and socio-cultural backgrounds will be mapped into differences in the implementations.

The basic assumptions of the constructionist perspective, from which Table 1 is derived, are already implicitly integrated into the Soft Systems Methodology (SSM). Authors in requirements engineering have been emphasising the interconnectedness of science, society, and technology [15] and the relevance of ethnographic techniques for eliciting requirements in their context [28], [14]. However, few specific guidelines have been provided to deal with the impact of emotions, beliefs, and values of the whole team involved in a requirements elicitation. There is also a shortage of guidelines to help elicit emotions, beliefs, and values from the visible and shared constructions of human action and interaction that occur in organizations. Finally, almost no ideas have been provided to structure requirements elicitation around the social dynamics of a learning process.

In the future, the authors intend to develop an approach that will structure requirements elicitation around the four processes that mold socially created realities and that will make use of the above guidelines and of strategies to effectively influence the transformation of emotions, values, and beliefs. An initial version of this approach has already been developed and tested in the field, but it needs to be improved in future action research projects. The authors do not intend to invent new techniques or a new method to guide requirements elicitation. Rather, they intend to provide a general framework in which existing methods and techniques could be integrated or reconstructed.

\section{References}

1. Arbnor, I., Bjerke, B.: Methodology for Creating Business Knowledge. Sage, Thousand Oaks, CA (1997)

2. Berry, D.M., Lawrence, B.: Requirements Engineering. IEEE Software 15:2 (March 1998) 26-29

3. Boje, D.M., Gephardt, R., Thatchenkery, T.J.: Postmodern Management and Organization Theory. Sage, Thousand Oaks, CA (1997)

4. Bolman, L.G., Deal, T.E.: Reframing Organizations: Artistry, Choice, and Leadership. Second Edition. Jossey-Bass, San Francisco, CA (1997)

5. Burke, W.W.: Organization Change: What We Know, What We Need to Know. Journal of Management Inquiry 4:2 (1995) 158-171 
6. Cialdini, R.B.: Influence: Science and Practice. Harper Collins College, New York, NY (1993)

7. Cummings, T.G., Worley, C.G.: Essentials of Organization Development and Change. South-Western College Press, Mason, OH (2000)

8. Dahlbom, B., Mathiassen, L.: Computers in Context: The Philosophy and Practice of Systems Design. Blackwell, Oxford, UK (1993)

9. Damásio, A.: damasio The Feeling of What Happens: Body and Emotion in the Making of Consciousness. Harcourt Brace, New York, NY (1999)

10. Davis, A., Hsia, P.: Giving Voice to Requirements. IEEE Software 11:2 (March 1994) $12-16$

11. Davis, A.M.: Software Requirements: Analysis and Specification. Prentice-Hall, Englewood Cliffs, NJ (1990)

12. Dickson, G.W., DeSanctis, G.: Information Technology and the Future Enterprise: New Models for Managers. Prentice Hall, Englewood Cliffs, NJ (2000)

13. Espejo, R., Schuhmannn, W., Schwaninger, M., Bilello, U.: Organizational Transformation and Learning: A Cybernetic Approach to Management. Jossey-Bass, Chicester, UK (1996)

14. Goguen, J.A., Jirotka, M.: Requirements Engineering: Social and Technical Issues. Academic Press, London, UK (1994)

15. Goguen, J.A.: Towards a Social, Ethical Theory of Information. In: Bowker, G., Gasser, L., Star, L., Turner, W.: Social Science Research, Technical Systems and Cooperative Work. Erlbaum, Mahwah, NJ (1997) 27-56

16. Greenwood, R., Hinings, C.R.: Understanding Strategic Change: the Contribution of Archetypes. Academy of Management Journal 36:5 (1993) 1052-1081

17. Hirschheim, R., Klein, H.K., Lyytinen, K.: Information Systems Development and Data Modeling: Conceptual and Philosophical Foundations. Cambridge University Press, Cambridge, UK (1995)

18. Iivari, J., Hirschheim, R., Klein, H.K.: A Paradigmatic Analysis Contrasting Information Systems Development Approaches and Methodologies. Information Systems Research 9:2 (1998) 164-193

19. Jick, T.D.: Accelerating change for competitive advantage. Organizational Dynamics 24:1 (1995) 77-82

20. Jones, M.O.: Studying Organizational Symbolism. Sage, Thousand Oaks, CA (1996)

21. Kafai, Y., Resnick, M.: Constructionism in Practice: designing, thinking, and learning in a digital world. Erlbaum, Mahwah, NJ (1996)

22. Kotonya, G., Sommerville, I.: Requirements Engineering. John Wiley \& Sons, West Sussex, UK (1998)

23. Kotter, J.P.: Leading Change. Harvard Business School Press, Cambridge, MA (1996)

24. Kramer, R.M., Neale, M.A.: Power and Influence in Organizations. Sage, Thousand Oaks, CA (1998)

25. Lincoln, Y.S., Guba, E.G.: Competing Paradigms in Qualitative Research. In: Denzin, N.K., Lincoln, Y.S.: Handbook of Qualitative Research. Sage, Thousand Oaks, CA (1994) 105-117

26. Lincoln, Y.S., Guba, E.G.: Paradigmatic Controversies, Contradictions, and Emerging Confluences. In: Denzin, N.K., Lincoln, Y.S.: Handbook of Qualitative Research. Sage, Thousand Oaks, CA (2000) 163-188

27. Lyytinen, K., Mathiassen, L., Ropponen, J.: Attention Shaping and Software Risk-A Categorical Analysis of Four Classical Risk Management Approaches. Information Systems Research 9:3 (1998) 233-255 
28. Macaulay, L.A.: Requirements Engineering. Springer, London, UK (1996)

29. Marion, R.: The Edge of Organization: Chaos and Complexity Theories of Formal Social Systems. Sage, Thousand Oaks, CA (1999)

30. Morgan, G.: Images of Organization. Sage, Thousand Oaks, CA (1997)

31. Nuseibeh, B., Easterbrook, S.: Requirements Engineering: A Roadmap. In: Finkelstein, A.: The Future of Software Engineering 2000. ACM, Limerick, Ireland (June 2000)

32. Palmer, I., Hardy, C.: Thinking about management. Sage, Thousand Oaks, CA (2000)

33. Papert, S.: Introduction. In: Harel, I.: Constructionist Learning. MIT Media Laboratory, Cambridge, MA (1990)

34. Parker, S., Wall, T.: Job and Work Design: Organizing Work to Promote WellBeing and Effectiveness. Sage, Thousand Oaks, CA (1998)

35. Ramos, I.M.P.: Aplica cões das Tecnologias de Informa cão que suportam as dimensões estrutural, social, política e simbólica do trabalho. Ph.D. Dissertation Departamento de Informática, Universidade do Minho, Guimarães, Portugal (2000)

36. Santos, I., Carvalho, J.Á.: Computer-Based Systems that Support the Structural, Social, Political and Symbolic Dimensions of Work. Requirements Engineering 3:2 (1998) 138-142

37. Robertson, S., Robertson, J.: Mastering the Requirements Process. AddisonWesley, Harlow, England (1999)

38. Schwandt, T.A.: Three Epistemological Stances for Qualitative Inquiry: Interpretivism, Hermeneutics, and Social Constructionism. In: Denzin, N.K., Lincoln, Y.S.: Handbook of Qualitative Research. Sage, Thousand Oaks, CA (2000) 189-213

39. Siddiqi, J., Shekaran, M.C.: Requirements Engineering: The Emerging Wisdom. IEEE Software 9:2 (March 1996) 15-19

40. Sommerville, I., Sawyer, P.: Requirements Engineering, A Good Practice Guide. John Wiley \& Sons, Chichester, UK (1997)

41. Spector, P.E.: Job Satisfaction: Application, Assessment, Causes, and Consequences. Sage, Thousand Oaks, CA (1997)

42. van Lamsweerde, A.: Requirements Engineering in the Year 00: A Research Perspective. Proceedings of 22nd International Conference on Software Engineering. ACM, Limerick, Ireland (June 2000) 
Table 1. Practical implications for elicitation of constructionist assumptions

\begin{tabular}{|c|c|c|c|}
\hline & Knowledge Creation & $\begin{array}{l}\text { Knowledge } \\
\text { Representation }\end{array}$ & $\begin{array}{l}\text { Requirements } \\
\text { Invention }\end{array}$ \\
\hline Goals & $\begin{array}{l}\text { Understand (1) human } \\
\text { action and interaction } \\
\text { that will be supported } \\
\text { by the software system } \\
\text { and }(2) \text { the meanings } \\
\text { behind that action. } \\
\text { Question and re-create } \\
\text { those meanings. }\end{array}$ & $\begin{array}{l}\text { Express a multivoiced } \\
\text { account of the reality } \\
\text { that we construct so- } \\
\text { cially. It includes the } \\
\text { voice of the elicitor and } \\
\text { all stakeholders of the } \\
\text { system. }\end{array}$ & $\begin{array}{l}\text { Reinvent the work reality } \\
\text { through the adoption of } \\
\text { a software system. }\end{array}$ \\
\hline $\begin{array}{l}\text { Process } \\
\text { structure }\end{array}$ & \multicolumn{3}{|c|}{$\begin{array}{l}\text { Process structure is the result of the joint effort of system's stakeholders and } \\
\text { elicitors for emancipation, fairness, and community empowerment. Its shape is } \\
\text { situational, i.e., it varies with organizational history and culture, and } \\
\text { resources involved. }\end{array}$} \\
\hline Product & $\begin{array}{l}\text { Reformulation of mental } \\
\text { constructions, recreation } \\
\text { of shared meanings, } \\
\text { awareness of contradic- } \\
\text { tions and paradoxes of } \\
\text { concepts and practices. } \\
\text { Development of a com- } \\
\text { mon and local language } \\
\text { to express feelings, per- } \\
\text { ceptions and concep- } \\
\text { tions. }\end{array}$ & $\begin{array}{l}\text { Expression of individual } \\
\text { and shared experience. }\end{array}$ & $\begin{array}{l}\text { Shared interpretations } \\
\text { of adequate support of } \\
\text { work. Cannot be discon- } \\
\text { nected from historical } \\
\text { and social contexts of } \\
\text { requirements creators. }\end{array}$ \\
\hline $\begin{array}{l}\text { Theoretical } \\
\text { frameworks }\end{array}$ & \multicolumn{3}{|c|}{$\begin{array}{l}\text { Inform the process with the values and beliefs held by elicitors and the } \\
\text { system's stakeholders. }\end{array}$} \\
\hline \multirow[t]{2}{*}{$\begin{array}{l}\text { Methods, } \\
\text { techniques, } \\
\text { and tools }\end{array}$} & $\begin{array}{l}\text { Inform the process with } \\
\text { the values held by elici- } \\
\text { tors and the system's } \\
\text { stakeholders. Help } \\
\text { create graphical and } \\
\text { textual elements of a } \\
\text { common language. }\end{array}$ & $\begin{array}{l}\text { Define the organization } \\
\text { of knowledge representa- } \\
\text { tions. }\end{array}$ & $\begin{array}{l}\text { Define the format in } \\
\text { which requirements are } \\
\text { expressed. }\end{array}$ \\
\hline & \multicolumn{3}{|c|}{$\begin{array}{l}\text { Have the potential of bias towards some stakeholders' voices and of forcing a } \\
\text { foreign language. }\end{array}$} \\
\hline $\begin{array}{l}\text { Role of } \\
\text { participants }\end{array}$ & $\begin{array}{l}\text { Co-creators of knowl- } \\
\text { edge, jointly nominate } \\
\text { the questions of interest. }\end{array}$ & $\begin{array}{l}\text { Co-creators of a lan- } \\
\text { guage to represent } \\
\text { knowledge, jointly } \\
\text { design outlets for } \\
\text { knowledge to be shared } \\
\text { more widely within and } \\
\text { outside the site. }\end{array}$ & $\begin{array}{l}\text { Co-inventors of a com- } \\
\text { mon future. }\end{array}$ \\
\hline $\begin{array}{l}\text { Reuse of } \\
\text { product }\end{array}$ & $\begin{array}{l}\text { Created knowledge is } \\
\text { local, transferable only } \\
\text { for sites where people } \\
\text { have similar experiences } \\
\text { and beliefs. }\end{array}$ & $\begin{array}{l}\text { Representations are } \\
\text { connected with the } \\
\text { context in which they } \\
\text { were created. If } \\
\text { transposed to a different } \\
\text { location, they may } \\
\text { invoke different mental } \\
\text { constructions in readers. }\end{array}$ & $\begin{array}{l}\text { Reuse of stakeholders' } \\
\text { requirements is problem- } \\
\text { atic because of their his- } \\
\text { torical and sociocultural } \\
\text { dimension. }\end{array}$ \\
\hline
\end{tabular}


Table 2. Work aspects that should guide the choice of participants

\begin{tabular}{|c|c|}
\hline Structural & $\begin{array}{l}\text { Participants should be representative of: } \\
\text { Formal roles } \\
\text { Tasks } \\
\text { Skills } \\
\text { Levels of authority } \\
\text { Accessed/produced information }\end{array}$ \\
\hline Social & $\begin{array}{l}\text { Participants should be representative of: } \\
\text { Communication skills } \\
\text { Negotiation skills } \\
\text { Informal roles } \\
\text { Degrees of motivation to change work practices } \\
\text { Participation in the shaping of organizational history } \\
\text { Willingness and experience in decision making processes } \\
\text { Professional status } \\
\text { Knowledge }\end{array}$ \\
\hline Political & $\begin{array}{l}\text { Participants should be representative of: } \\
\text { Individual interests } \\
\text { Form of power held: organizational authority, control of scarce } \\
\text { resources, control of the definition of formal arrangements, } \\
\text { restricted access to key information, control of organizational } \\
\text { borders, control of core activities, member of a strong coalition, } \\
\text { charisma }\end{array}$ \\
\hline Symbolic & $\begin{array}{l}\text { Participants should be representative of: } \\
\text { Use of jargon } \\
\text { Use of proverbs, slogans or metaphors } \\
\text { Relevant beliefs and superstitions } \\
\text { Use of humor } \\
\text { Story telling } \\
\text { Responsibilities for symbolic events } \\
\text { Ways of instigating social routines and taken for granted techniques } \\
\text { to perform a task } \\
\text { Wavs of conceiving the work space }\end{array}$ \\
\hline
\end{tabular}


Table 3. Dimensions of human action in organizations

\begin{tabular}{|c|c|}
\hline Structural & $\begin{array}{l}\text { Relevant organizational goals, objectives, and strategies } \\
\text { Tasks, processes, rules, regulations, and procedures } \\
\text { Communication channels and exchanged information } \\
\text { Coordination and control } \\
\text { Formal roles } \\
\text { How authority is distributed } \\
\text { Needs of system support to work } \\
\text { Relevant organizational and technological knowledge to be able to } \\
\text { perform tasks }\end{array}$ \\
\hline Social & $\begin{array}{l}\text { Shared goals and objectives } \\
\text { Performance expectations } \\
\text { Rewards or punishments for performance } \\
\text { Motivation factors } \\
\text { Informal roles and communication } \\
\text { Personal knowledge and its impact on work concepts, practices, and } \\
\quad \text { relationships } \\
\text { Fostered participation in decision making } \\
\text { Use of individual and group skills }\end{array}$ \\
\hline Political & $\begin{array}{l}\text { Personal interests relating performed tasks, career progression, and } \\
\text { private life } \\
\text { Coalitions } \\
\text { Individual or group power plays } \\
\text { Conflict of interests } \\
\text { Negotiation processes: concepts, and practices }\end{array}$ \\
\hline Symbolic & $\begin{array}{l}\text { Symbols used to deal with ambiguity and uncertainty } \\
\text { Shared values and beliefs } \\
\text { Common language } \\
\text { Relevant myths, stories, and metaphors } \\
\text { Rituals and ceremonies } \\
\text { Relevant messages organizational, work, or system stakeholders } \\
\text { Legitimized ways of expressing emotions }\end{array}$ \\
\hline
\end{tabular}

